\title{
The Antibiotype of Some Lactic Acid Bacteria Probiotic Strains from the MIUG Collection
}

\author{
Vasilica BARBU*, Ana-Maria NEDELCU \\ Faculty of Food Science and Engineering, University “Dunarea de Jos” Galati, Romania, 111 Domnească \\ Street, 800201 Galați, Romania \\ *Corresponding author, email: vasilica.barbu@ugal.ro
}

Bulletin UASVM Animal Science and Biotechnologies 71(2) / 2014,

Print ISSN 1843-5262; Electronic ISSN 1843-536X

DOI. 10.15835/buasvmcn-asb:10300

\begin{abstract}
Antibiotic resistance of microorganisms is an acute problem of medical importance at present. Beside the pathogen's antibiotype is also studied the antibioresistance of some probiotic lactic acid bacteria (LAB) because their administration is often associated with some antibiotics. Many researches have speculated that commensal bacteria like LAB may act as reservoirs of antibioresistance genes similar to human pathogens.

This study is started at the necessity to investigate the bacterial antibioresistance patterns of twenty strains of LAB, from the MIUG collection, isolated from epiphytic microbiote of grain, from the faeces of chickens or of infants. The purpose is to identify the risk factors for the colonization process with possible impact upon the human pathology.

The antibioresistance spectrum was determined by disk diffusion method (Kirby-Bauer), conforming to the NCCLS 2007 standard. It was observed the multiresistence phenomenon. The La5 and FB3 strains ware characterized by simultaneous resistance to 12 antibiotics. At DO, TE, CIP, OX, NOR, CRO were not detected susceptible strains probably due to the presence of multiresistance plasmidial markers. The highest susceptibility is registered to IMP (85\% of the strains), to AML (80\%) and to TOB (65\%). FG2 strain (isolated from the faeces of chickens) is susceptible to most antibiotics.

The multiresistence of pathogenic microorganism is a real disadvantage that makes difficult treating diseases. The resistance to antibiotics of LAB makes possible the administration concomitant with them, to fulfill their probiotic role. But it must be taken into account the horizontal transmission of multiresistence between bacterial populations in the ecosystem tract.
\end{abstract}

Keywords: antibiotype, lactic acid bacteria, multiresistance, probiotics

\section{INTRODUCTION}

According to the European Commission (2008) it is estimated that in the last sixty years, up to 107 tons of antibiotics were launched in the biosphere. This represented a very strong selective pressure, which conducted to the apparition of new bacterial strains resistant to antibiotics. In a time when conventional antibiotics are becoming increasingly less effective for treatment of infections, the relationship between bacteria and antimicrobial resistance is becoming more and more complicated (Moura et al., 2009). For several decades, studies on the selection and dissemi- nation of antibiotic resistance have focused mainly on clinically relevant bacterial species. But, recently, many investigators have speculated that commensal bacteria, like lactic acid bacteria (LAB), may act as reservoirs of antibiotic resistance genes similar to those found in human pathogens (Mathur and Singh, 2005). When antibiotic resistance is found to all strains of one species it is known as the intrinsic or natural resistance. Whereas, when a strain of a usually susceptible species is found resistant to a new antimicrobial, it is named acquired resistance. Acquired resistance can be gained either by the addition of new genes 
(genes acquired by the genetic recombination mechanisms such as transformation, conjugation or transduction) or to the mutation of their own genes. The main threat associated with LAB is that they can transfer resistance genes to the pathogenic bacteria.

Because many important human pathogens use quorum sensing (QS) to regulate virulence, strategies designed to interfere with these signaling systems will likely have broad applicability for biological control of disease-causing organisms (Kievit and Iglewski, 2000). The mechanisms of probiotic action are most probably multifactorial, involving a variety of effectors signals, cell types and receptors (Sherman et al., 2009). The discovery of QS in human pathogens has led to considerable interest in developing new therapeutic interventions to interfere with these signaling molecules.

By EU Project ACE-ART (Assessment and Critical Evaluation of Antibiotic Resistance Transferability in Food Chain) new genes, which encoding for antimicrobial resistance, have being sequenced and new mobile genetic elements have been identified in bacteria. Genome or metagenome analysis for several bacterial species, including LAB, used as feed additives or in human food opens new perspectives of investigation concerning natural or acquired antibioresistance.

Panel on Additives and Products or Substances used in Animal Feed (FEEDAP) proposes evaluation bacterial strains used as feed additives or in human food regarding to their antibiotics resistance and considers that strains of bacteria that convey an acquired resistance to antimicrobials should therefore be banned from marketing, unless it can be demonstrated that it is a consequence of chromosomal mutation(s) (EU, 2005)

Because the LAB are present in the gastrointestinal ecosystem and are voluntarily consumed along with some foods that contain them, there have emerged a series of concerns concerning the antibioresistance of these species of probiotic bacteria. For example, LAB resistant to certain antibiotics may be beneficial for the host (human or animal), helping to maintain the homeostasis in the gastrointestinal tract in cases of diarrhea caused by antibiotics. However, there is a risk of the ability of these resistant strains to convey resistance genes to other bacteria, potentially pathogenic, from the intestinal ecosystem. This may complicate the treatment of a bacterial infection. Therefore, the possibility of movement of the genes coding for antibiotic resistance, from the beneficial LAB through the food chain of animals and humans is of particular concern.

Lactobacillus species were identified as being sensitive to many inhibitors of cell wall synthesis, such as penicillin and ampicillin (Danielsen and Wind, 2003, Coppola et al., 2005). However, to glycopeptides such as vancomycin, most Lactobacillus species (with the exception of heterofermentative) were shown to be resistant. This is an intrinsic resistance to vancomycin (Tynkkynen et al., 1998) and should not be compared with plasmid-mediated acquired resistance, met in enterococci (Leclercq et al., 1992).

Lactobacillus species are usually susceptible to chloramphenicol, erythromycin and clindamycin, antibiotics that inhibit protein synthesis (Coppola et al., 2005; Klare et al., 2007). In addition, resistance to nucleic acid synthesis inhibitors, such as trimethoprim, appears to be of chromosomal nature (Ammor et al., 2007).

Resistance to tetracycline was observed more frequently among species of Lactobacillus and proved to have a wide range of minimal inhibitory concentration (MIC) (Korhonen et al., 2008). A multimodal distribution of MIC, probably due to the diversity of tetracycline resistance mechanisms confers different levels of sensitivity (Roberts, 2005). The molecular methods should explain the nature of resistance to tetracycline (mutation or mobile genetic elements).

Potentially transferable genes to lactic acid bacteria have been described in several studies and were reviewed by Ammor et al., 2007. The most studied genes were tet(M) for resistance to tetracycline and $\operatorname{erm}(\mathrm{B})$ for resistance to erythromycin, followed by the genes encoding resistance to chloramphenicol (Lin et al., 1996; Gevers et al., 2003).

This study is started at the necessity to investigate the bacterial antibioresistance patterns of twenty strains of LAB, from the MIUG microorganisms collection of Food Science and Engineering Faculty ("Dunarea de Jos" University of Galati), isolated from epiphytic microbiote of grain, from the faeces of chickens or of infants. The purpose is to identify the risk factors for the 
colonization process with possible impact upon the human pathology.

\section{MATERIALS AND METHODS}

The first step in phenotypic characterizing the species of LAB regarding the antibiotic sensitivity or resistance is establishing the standard method. Standardization involves adjusting inoculum and incubation time (Egervärn et al., 2007), choosing the correct testing methods and specific medium. There were also used: the microdilution method (Kushiro et al., 2009), the E-test (Danielsen and Wind, 2003), the agar dilution (Florez et al., 2005) and the diffusion method (Gevers et al, 2000). Moreover, different growth media were used for testing, including MRS, M17 and Muller-Hinton (Huys et al., 2002; Hummel et al., 2007).

Klare and his peers, in 2005, developed a new medium for testing the antibiotype of Lactobacillus, Lactococcus, Pediococcus and Bifidobacteria - LSM medium. Subsequently, there were several studies on antibiotic resistance of LAB using LSM broth and agar (Klare et al., 2007; Huys et al., 2008; Devirgiliis et al., 2009, Kushiro et al., 2009) for comparing the results of MIC obtained in different laboratories.
We used a total of twenty strains of probiotic LAB from the MIUG collection (Tab.1): some are isolated from epiphytic microbiota of cereals or vegetables, other from poultry faeces or of infants (fostered exclusively with breast milk). Some strains are commercial, while others come from a different curator (MICROGEN-Bucharest).

The antibioresistance spectrum was determined by disk diffusion method (KirbyBauer). Lactic acid bacteria strains were cultivated over-night on MRS broth and, for the antibioresistance test, we used the MRS agar medium. Theinoculum was preparedincomparison to a $0.5 \mathrm{McF}$ arland standard, being equivalent to a bacterial suspension containing between $1-2 \cdot 10^{8}$ $\mathrm{CFU} / \mathrm{ml}$. We tested the antibiotype of twenty lactic acid bacteria strains to nineteen antibiotics:

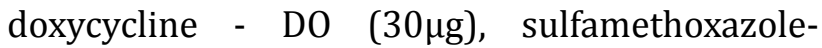

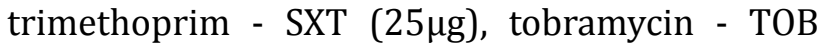
$(10 \mu \mathrm{g})$, ampicillin - AMP $(10 \mu \mathrm{g})$, vancomycin - VA $(30 \mu \mathrm{g})$, tetracycline - TE $(30 \mu \mathrm{g})$, ciprofloxacin CIP $(5 \mu \mathrm{g})$, amoxicillin - AML $(25 \mu \mathrm{g})$, amoxicillin clavulanate AMC $(10 \mu \mathrm{g})$, imipenem - IPM $(10 \mu \mathrm{g})$, colistin sulphate - CT $(25 \mu \mathrm{g})$, cefuroxime - CXM $(30 \mu \mathrm{g})$, norfloxacin - NOR $(10 \mu \mathrm{g})$, gentamicin CN $(10 \mu \mathrm{g})$, oxacillin - OX $(1 \mu \mathrm{g})$, erythromycin - E

Tab. 1. LAB strains used in the study

\begin{tabular}{ccc}
\hline No. & Species/code & Source / Curator \\
\hline 1 & Weissella confusa (L) & Rye /MIUG \\
\hline 2 & Streptococcus lactis (SL) & Rye /MIUG \\
\hline 3 & Enterococcus faecium $V L$ 28 & MICROGEN \\
\hline 4 & Enterococcus faecium (VL 43) & MICROGEN \\
\hline 5 & Lactobacillus acidophilus GM 14 & MICROGEN \\
\hline 6 & Lactobacillus plantarum (ATCC 8014) & MICROGEN \\
\hline 7 & Lb. delbrueckii sp. bulgaricus. (LDB) & MICROGEN \\
\hline 8 & Lactobacillus johnsonii (La) & MICROGEN \\
\hline 9 & Lactobacillus brevis (GAL16) & Wheat/MIUG \\
\hline 10 & Lactobacillus plantarum (GAL13) & Wheat/MIUG \\
\hline 11 & Lactobacillus plantarum (GAL15) & Wheat /MIUG \\
\hline 12 & Lactobacillus casei 431 & Commercial \\
\hline 13 & Bifidobacterium lactis (BB12) & Commercial \\
\hline 14 & Lactobacillus acidophilus (La $)$ & Commercial \\
\hline 15 & Lactobacillus sp.( (M1) & Pickles/MIUG \\
\hline 16 & Lactobacillus sp.(FG1) & Poultry faeces /MIUG \\
\hline 17 & Lactobacillus sp.( (FG2) & Poultry faeces/MIUG \\
\hline 18 & Lactobacillus sp.( (FG4) & Poultry faeces /MIUG \\
\hline 19 & Lactobacillus sp.( (FB3) & Infants faeces/MIUG \\
\hline 20 & Lactobacillus sp.( (FB6) & Infants faeces/MIUG \\
\hline
\end{tabular}


$(15 \mu \mathrm{g})$, kanamycin - K $(30 \mu \mathrm{g})$, ceftriaxone - CRO $(30 \mu \mathrm{g})$, streptomycin - S $(10 \mu \mathrm{g})$.

\section{RESULTS AND DISCUSSION}

The interpretation of results was made by the diameters of the inhibition zones, conforming to the Clinical Laboratory Standards Institute (CLSI) standard. The CLSI publication (Performance Standards for Antimicrobial Disk Susceptibility Tests Approved Standard 9th Edition), represents the standard for clinical laboratories performing susceptibility testing today. Results are expressed with the abbreviations S - sensitive, I - intermediate, $\mathrm{R}$ - resistant, according to Annex 1.

From the analysis of Table 2 we can observe that the largest number of susceptible strains registers to imipenem ( $85 \%$ of the strains), to amoxicillin $(80 \%)$ and to tobramycin $(65 \%)$ that inhibit cell wall synthesis or protein synthesis through blocking specific sites from the small ribosomal subunit. The highest percentage of resistant strains (95\%) is registered to vancomycin (of glycopeptides) and quinolones (ciprofloxacin and norfloxacin), antibiotics that inhibit either the mechanism of cell wall synthesis or bacterial DNA replication by blocking DNA gyrase. Over $85 \%$ of strains are resistant to colistin (a type of cyclic polypeptide), doxycycline and tetracycline (of tetracyclines).

Tab. 2. The percentage of LAB strains sensitive / resistant for the antibiotics analyzed

\begin{tabular}{ccc}
\hline Antibiotics & $\begin{array}{c}\text { Susceptible } \\
\text { strains } \%\end{array}$ & $\begin{array}{c}\text { Resistance } \\
\text { strains } \%\end{array}$ \\
\hline DO & 10 & 85 \\
\hline SXT & 50 & 30 \\
\hline TOB & 65 & 30 \\
\hline AMP & 20 & 25 \\
\hline VA & 5 & 95 \\
\hline TE & 0 & 85 \\
\hline CIP & 0 & 95 \\
\hline AML & 80 & 10 \\
\hline AMC & 50 & 0 \\
\hline IPM & 85 & 10 \\
\hline CT & 10 & 90 \\
\hline CXM & 35 & 40 \\
\hline NOR & 0 & 90 \\
\hline CN & 40 & 55 \\
\hline OX & 0 & 65 \\
\hline E & 25 & 10 \\
\hline K & 55 & 0 \\
\hline CRO & 0 & 70 \\
\hline S & 25 & 70 \\
\hline & &
\end{tabular}

From all the analysed semisynthetic $\beta$ lactam antibiotics, the strains manifested the highest resistance to oxacillin, given the fact that oxacillin has a limited antibacterial spectrum. Ampicillin and amoxicillin have a broader spectrum, having bactericidal activity against Gram positive and Gram-negative bacteria and many strains exhibit sensitivity to these. The amoxicillin clavulanate possesses the bicyclic clavam system that inhibits $\beta$-lactamases through which the most penicillinresistant microorganisms counteract the effect of $\beta$-lactam antibiotics. Obviously, therefore, the strains are more susceptible to AMC.

Cephalosporins, which have the commonstructure the cephem nucleus have an expanded antibacterial spectrum. The third generation of cephalosporins (ceftriaxone - CRO) is even resistant to $\beta$-lactamases, but is moderately active against Gram-positive bacteria. The strains of LAB are considered more sensitive to Cefuroxime, a second-generation cephalosporin, which has some stability $\beta$-lactamase (Fig. 1).

Imipenem is a $\beta$-lactam antibiotic from the Carbapenem category, with a broad spectrum of

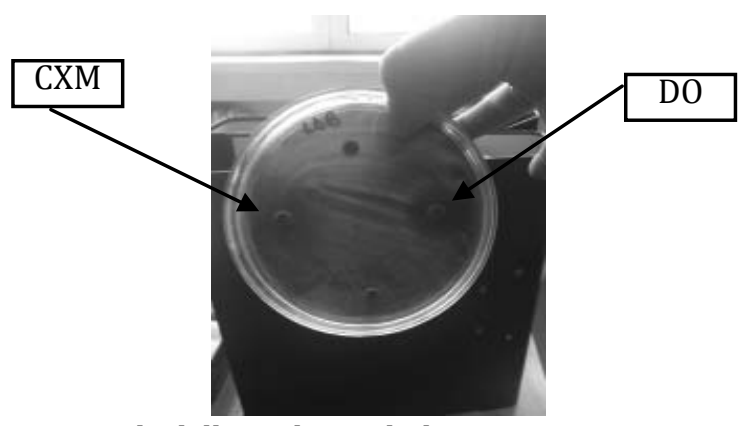

Fig.1. Lb. delbrueckii sp. bulgaricus strain, sensitive to cefuroxime (CXM) and doxycycline (DO)

antibacterial activity, including anaerobic bacteria. LAB analyzed showed the widespread sensitivity to this antibiotic (Fig. 2).

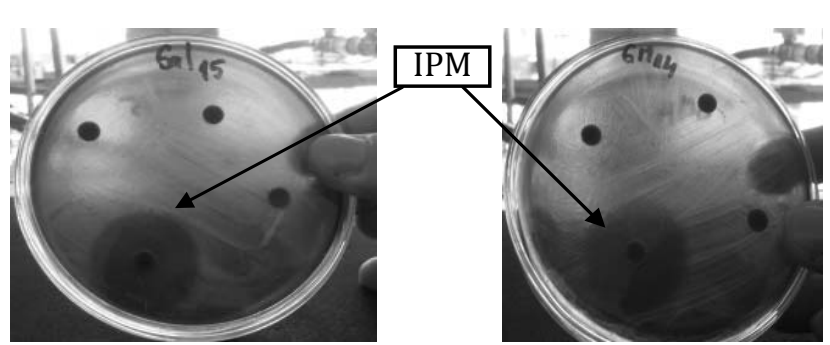

Fig. 2. Lactobacillus plantarum Gal15 strains (left) and Lactobacillus acidophilus GM14 strain (right), susceptible to imipenem (IPM) 
Annex 1. The antibiotype of LAB strains

\begin{tabular}{|c|c|c|c|c|c|c|c|c|c|c|c|c|c|c|c|c|c|c|c|}
\hline & CXM & DO & CT & IPM & E & $\mathrm{S}$ & OX & VA & AMC & SXT & NOR & CRO & $\mathrm{K}$ & AMP & TOB & $\mathrm{TE}$ & CIP & AML & $\mathrm{CN}$ \\
\hline Gal 13 & $S$ & $\mathrm{R}$ & $\mathrm{R}$ & $\mathrm{R}$ & I & I & I & $\mathrm{R}$ & $\mathrm{S}$ & I & $\mathrm{R}$ & $\mathrm{R}$ & $\mathrm{S}$ & I & $\mathrm{S}$ & $\mathrm{R}$ & $\mathrm{R}$ & $\mathrm{S}$ & $\mathrm{R}$ \\
\hline Gal 15 & I & $\mathrm{R}$ & $\mathrm{R}$ & $S$ & I & $\mathrm{R}$ & $\mathrm{R}$ & $\mathrm{R}$ & I & $\mathrm{S}$ & $\mathrm{R}$ & I & $\mathrm{S}$ & $\mathrm{I}$ & $S$ & $\mathrm{R}$ & $\mathrm{R}$ & $S$ & $S$ \\
\hline Gal 16 & $\mathrm{I}$ & $\mathrm{R}$ & $\mathrm{S}$ & $\mathrm{S}$ & $\mathrm{S}$ & $\mathrm{S}$ & $\mathrm{R}$ & $\mathrm{R}$ & $\mathrm{I}$ & $\mathrm{R}$ & $\mathrm{R}$ & $R$ & $S$ & $\mathrm{R}$ & $S$ & $\mathrm{R}$ & $\mathrm{R}$ & $S$ & $S$ \\
\hline $\mathrm{L}$ & I & $\mathrm{S}$ & $\mathrm{R}$ & $\mathrm{S}$ & $\mathrm{R}$ & $\mathrm{R}$ & I & $\mathrm{R}$ & $S$ & I & I & $\mathrm{R}$ & I & I & $\mathrm{S}$ & $\mathrm{R}$ & $\mathrm{R}$ & $\mathrm{S}$ & $\mathrm{R}$ \\
\hline SL & $\mathrm{R}$ & $\mathrm{R}$ & $\mathrm{R}$ & $S$ & $S$ & $\mathrm{~S}$ & $\mathrm{R}$ & $\mathrm{R}$ & $S$ & $S$ & $\mathrm{R}$ & $\mathrm{I}$ & $\mathrm{S}$ & $S$ & $\mathrm{R}$ & $\mathrm{R}$ & $\mathrm{I}$ & $S$ & $\mathrm{R}$ \\
\hline LDB & $S$ & $\mathrm{~S}$ & $\mathrm{R}$ & $\mathrm{S}$ & $\mathrm{I}$ & $\mathrm{R}$ & $\mathrm{R}$ & $\mathrm{R}$ & $\mathrm{I}$ & $\mathrm{S}$ & $\mathrm{I}$ & $\mathrm{I}$ & $\mathrm{I}$ & $\mathrm{I}$ & $S$ & $\mathrm{I}$ & $\mathrm{R}$ & $\mathrm{R}$ & $S$ \\
\hline VL28 & $\mathrm{R}$ & $\mathrm{R}$ & $\mathrm{R}$ & $\mathrm{S}$ & I & $\mathrm{R}$ & $\mathrm{R}$ & $\mathrm{R}$ & $S$ & I & $\mathrm{R}$ & I & I & $\mathrm{R}$ & $\mathrm{S}$ & $\mathrm{R}$ & $\mathrm{R}$ & $\mathrm{S}$ & I \\
\hline VL43 & $S$ & $\mathrm{R}$ & $\mathrm{R}$ & $S$ & $\mathrm{I}$ & $\mathrm{R}$ & $\mathrm{R}$ & $\mathrm{R}$ & $\mathrm{I}$ & $S$ & $\mathrm{R}$ & I & $S$ & $\mathrm{R}$ & $S$ & $\mathrm{R}$ & $\mathrm{R}$ & $\mathrm{R}$ & $\mathrm{R}$ \\
\hline GM14 & $S$ & $\mathrm{I}$ & $\mathrm{S}$ & $\mathrm{S}$ & $\mathrm{I}$ & $\mathrm{R}$ & $\mathrm{R}$ & $\mathrm{R}$ & $\mathrm{S}$ & $\mathrm{R}$ & $\mathrm{R}$ & $\mathrm{R}$ & $S$ & $\mathrm{~S}$ & $\mathrm{R}$ & $\mathrm{R}$ & $\mathrm{R}$ & $\mathrm{I}$ & $\mathrm{R}$ \\
\hline La1 & S & $\mathrm{R}$ & $\mathrm{R}$ & S & $\mathrm{S}$ & $\mathrm{S}$ & $\mathrm{R}$ & $\mathrm{R}$ & I & $\mathrm{R}$ & $\mathrm{R}$ & $\mathrm{R}$ & $\mathrm{S}$ & $\mathrm{R}$ & $\mathrm{S}$ & $\mathrm{R}$ & $\mathrm{R}$ & S & S \\
\hline La5 & $\mathrm{R}$ & $\mathrm{R}$ & $\mathrm{R}$ & $S$ & $\mathrm{R}$ & $\mathrm{R}$ & $\mathrm{I}$ & $\mathrm{R}$ & $S$ & $\mathrm{R}$ & $\mathrm{R}$ & $\mathrm{R}$ & $\mathrm{I}$ & $\mathrm{I}$ & $\mathrm{R}$ & $\mathrm{R}$ & $\mathrm{R}$ & $S$ & $S$ \\
\hline L.casei & $\mathrm{R}$ & $\mathrm{R}$ & $\mathrm{R}$ & $\mathrm{R}$ & $\mathrm{S}$ & $\mathrm{R}$ & $\mathrm{R}$ & $\mathrm{R}$ & $S$ & $S$ & $\mathrm{R}$ & $\mathrm{R}$ & $\mathrm{I}$ & $S$ & $S$ & $\mathrm{R}$ & $\mathrm{R}$ & $\mathrm{S}$ & $\mathrm{R}$ \\
\hline BB12 & I & $\mathrm{R}$ & $\mathrm{R}$ & S & I & $\mathrm{S}$ & I & $\mathrm{R}$ & I & $\mathrm{R}$ & $\mathrm{R}$ & $\mathrm{R}$ & I & I & $\mathrm{R}$ & $\mathrm{R}$ & $\mathrm{R}$ & $\mathrm{S}$ & S \\
\hline ATCC & $\mathrm{R}$ & $\mathrm{R}$ & $\mathrm{R}$ & $S$ & $\mathrm{I}$ & $\mathrm{R}$ & $\mathrm{R}$ & $\mathrm{R}$ & $\mathrm{I}$ & $S$ & $\mathrm{R}$ & $\mathrm{I}$ & $S$ & $\mathrm{I}$ & $S$ & $\mathrm{I}$ & $\mathrm{R}$ & $S$ & $\mathrm{R}$ \\
\hline M1 & $\mathrm{R}$ & $\mathrm{R}$ & $\mathrm{R}$ & $S$ & $\mathrm{I}$ & $\mathrm{R}$ & $\mathrm{R}$ & $\mathrm{R}$ & I & $S$ & $\mathrm{R}$ & $\mathrm{R}$ & $S$ & I & $S$ & $\mathrm{R}$ & $\mathrm{R}$ & $S$ & $S$ \\
\hline FG1 & $S$ & $\mathrm{R}$ & $\mathrm{R}$ & $S$ & $\mathrm{~S}$ & $\mathrm{R}$ & $\mathrm{R}$ & $\mathrm{R}$ & I & $S$ & $\mathrm{R}$ & $\mathrm{R}$ & $\mathrm{S}$ & $\mathrm{R}$ & I & $\mathrm{R}$ & $\mathrm{R}$ & I & $S$ \\
\hline FG2 & $S$ & $\mathrm{R}$ & $\mathrm{R}$ & $\mathrm{I}$ & $\mathrm{I}$ & $S$ & $\mathrm{R}$ & $S$ & $S$ & $S$ & $\mathrm{R}$ & $\mathrm{R}$ & $\mathrm{S}$ & $S$ & $S$ & $\mathrm{I}$ & $\mathrm{R}$ & $S$ & $\mathrm{R}$ \\
\hline FG4 & $\mathrm{I}$ & $\mathrm{R}$ & $\mathrm{R}$ & $S$ & $\mathrm{I}$ & $\mathrm{R}$ & $\mathrm{I}$ & $\mathrm{R}$ & $S$ & $S$ & $\mathrm{R}$ & $\mathrm{R}$ & I & $S$ & $\mathrm{R}$ & $\mathrm{R}$ & $\mathrm{R}$ & $S$ & $\mathrm{R}$ \\
\hline FB3 & $\mathrm{R}$ & $\mathrm{R}$ & $\mathrm{R}$ & $\mathrm{S}$ & I & $\mathrm{R}$ & I & $\mathrm{R}$ & $\mathrm{S}$ & $\mathrm{R}$ & $\mathrm{R}$ & $\mathrm{R}$ & I & I & $\mathrm{R}$ & $\mathrm{R}$ & $\mathrm{R}$ & $S$ & $\mathrm{R}$ \\
\hline FB6 & $\mathrm{R}$ & $\mathrm{R}$ & $\mathrm{R}$ & $S$ & $\mathrm{I}$ & $\mathrm{R}$ & I & $\mathrm{R}$ & $\mathrm{I}$ & $\mathrm{I}$ & $\mathrm{R}$ & $R$ & I & $\mathrm{I}$ & $\mathrm{S}$ & $\mathrm{R}$ & $\mathrm{R}$ & $S$ & $\mathrm{R}$ \\
\hline
\end{tabular}

The macrolides have a large aliphatic ring (fourteen atoms in the case of erythromycin) and they block the active aminoacyl site of the 50S ribosomal subunit and thus inhibit the elongation of the polypeptide chain. Most strains of LAB have an intermediate phenotype to this antibiotic (Annex 1).

Many strains of lactic acid bacteria studied exhibit a phenomenon of cross-resistance to aminoglycoside antibiotics. The percentage varies within a relatively wide domain, from a $25 \%$ sensitive strain to streptomycin, $40 \%$ to gentamicin, $55 \%$ to kanamycin, up to a $65 \%$ compared to Tobramycin. It is considered a low level resistance because it manifested to the usual dose of $10-30 \mu \mathrm{g}$. Increasing the dose to $120 \mu \mathrm{g}$, the strains become susceptible. Resistance to aminoglycosides such as neomycin, kanamycin, streptomycin and gentamycin was observed more frequently in lactobacilli as shown in several studies (Danielsen and Wind, 2003; Coppola et al., 2005; Zhou et al., 2005). MRS medium was shown to significantly affect phenotypic characterization of LAB to aminoglycoside antibiotics (Huys et al., 2002).

For the glycopeptide antibiotics type (vancomycin) or quinolones type (norfloxacin and ciprofloxacin) LAB studied showed the stronger resistance. Only the strain FG2 contradicts this rule. It is a quite commonly reported phenomenon of resistance to vancomycin and teicoplanin, which are antibiotics used to treat severe kidney or digestive infections with multiresistant bacteria. Most of them become resistant even to these antibiotics because of the phenomenon of horizontal transfer by conjugation process.

Strains isolated from poultry faeces all belong to the genus Lactobacillus, but the species is not yet known. It should be noted that the strain FG2 is the only sensitive to vancomycin of the twenty analyzed strains. This susceptibility phenotype increases their importance as probiotics. FG2 strain (isolated from the faeces of chickens) is susceptible to 8 antibiotics, is resistant only to DO, CT, OX, NOR, CRO, CIP, CN intermediate phenotype manifest IPM, E, TE (Fig.3 and Tab. 1).

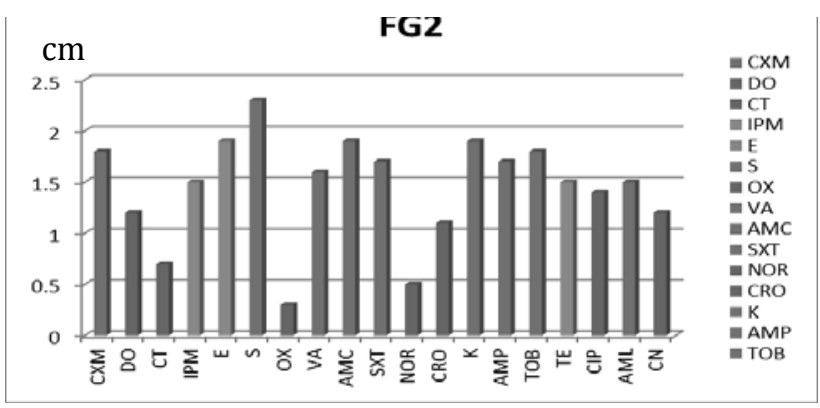

Fig. 3. The antibiotype of the Lactobacillus sp. FG2 strain

Weissella confusa (L) and Bifidobacterium lactis BB12 are two remarkable strains through their probiotic potential. Nevertheless, both show the multiple resistance phenomenon having 
genetic markers that confer resistance to various antibiotics. Weissella confusa strain L is sensitive to antibiotics IPM (imipenem), AML (amoxiciclin) AMC (amoxicillin clavulanate), K (kanamycin), TOB (tobramycin) and doxycycline (DO) (Fig. 4) and resistance to TE (tetracycline), TC (colistin sulfate), E (erythromycin), VA (vancomycin), CN (gentamicin), S (streptomycin), CRO (ceftriaxone), CIP (ciprofloxacin).

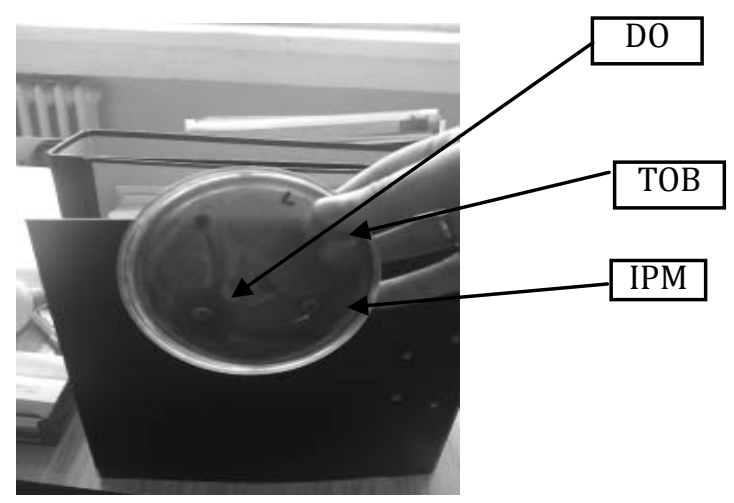

Fig. 4. Weissella confusa L strain, sensitive to DO, TO and IPM

No strain is sensitive to tetracycline (TE), Ciprofloxacin (CIP), Norfloxacin (NOR), Oxacillin (OX) and Ceftriaxone (CRO). Only $10 \%$ are sensitive to polypeptides such as Colistin -CT and $50 \%$ are sensitive to sulfonamides as trimethoprim -SXT, giving the complete picture of multidrug resistant (MDR) lactic acid bacteria analyzed. This could be an advantage because these probiotics strains can be administered with antibiotics for the treatment of pathogens with the aim of restoring the normal intestinal microbiota.

\section{CONCLUSION}

MDR phenomenon was found in most strains of lactic acid bacteria.

LA5 strain (Lactobacillus acidophilus) displayed resistance to twelve antibiotics (CXM, DO, CT, E, S, SXT, NOR, CRO, TOB, TE, CIP) of the nineteen tested.

The FB3 strain (isolated from infant feces) was characterized by resistance to twelve antibiotics (CXM, DO, CT, S, SXT, NOR, CRO, TOB, TE, CIP, CN) of nineteen tested.

To tetracycline, ciprofloxacin, norfloxacin, oxaciclină and ceftriaxone, susceptible strains were not detected.
Many strains of LAB studied exhibit a phenomenon of cross-resistance to aminoglycoside antibiotics.

If the multiresistance of pathogens is a real drawback hampering the treatment of diseases, in LAB's case, their resistance to antibiotics is a positive side in that it makes possible their concomitant administration with antibiotics to carry out their probiotic role in the intestinal tract. But, even in their case, it is appropriate to be taken into consideration the horizontal transmission of multidrug-resistance genes toward bacterial populations from the intestinal ecosystem because most of them provoke various diseases that are becoming increasingly difficult to treat.

\section{REFERENCES}

1. ACE-ART: Assessment and Critical Evaluation of Antibiotic Resistance Transferability in Food Chain, EU Project. (CT2004-506214). http://www.aceart.net/

2. Ammor MS, Florez, A.B. and Mayo, B. (2007). Antibiotic resistance in nonenterococcal lactic acid bacteria and bifidobacteria. Food Microbiol 24, 559-570.

3. Coppola R, Succi M, Tremonte P, Reale A, Salzano G and Sorrentino E (2005). Antibiotic susceptibility of Lactobacillus rhamnosus strains isolated from Parmigiano Reggiano cheese. Lait 85, 193-204.

4. Danielsen M and Wind A (2003). Susceptibility of Lactobacillus spp. To antimicrobial agents. Int J Food Microbiol 82, 1-11.

5. Devirgiliis C, Coppola D, Barile S, Colonna B and Perozzi $G$ (2009). Characterization of the Tn916 conjugative transposon in a food -borne strain of Lactobacillus paracasei. Appl Environ Microbiol 75, 3866-3871.

6. Egervarn M., Lindmark H, Roos S, Huys G and Lindgren S (2007). Effects of inoculum size and incubation time on broth microdilution susceptibility testing of lactic acid bacteria. Antimicrob Agents Chemother.

7. European Commission (2005). Opinion of the scientific panel on additives and products or substances used in animal feed on the updating of the criteria used in the assessment of bacteria for resistance to antibiotics of human or veterinary importance. The EFSA J 223, 1-12.

8. European Commission (2008). Technical guidance prepared by the Panel onAdditives and Products or Substances used in Animal Feed (FEEDAP) on the update of the criteria used in th e assessment of bacterial resistance to antibiotics of human or veterinary importance. The EFSA J, 1-15.

9. Florez AB., Delgado S and Mayo B (2005). Antimicrobial susceptibility of lactic acid bacteria isolated from a cheese environment. Can J Microbiol.

10. Gevers D, Huys G and Swings J (2003). In vitro conjugal transfer of tetracycline resistance from Lactobacillus isolates to other Gram-positive bacteria. FEMS Microbiol Lett 225, 125-130. 
11. Gevers D, Huys G, Devlieghere F, Uyttendaele M, Debevere $\mathrm{J}$ and Swings J (2000). Isolation and identification of tetracycline resistant lactic acid bacteria from pre-packed sliced meat products. Syst Appl Microbiol 23, 279-284.

12. Hummel AS, Hertel C, Holzapfel WH and Franz CM (2007). Antibiotic resistances of starter and probiotic strains of lactic acid bacteria. Appl Environ Microbiol 73.

13. Huys G, D’Haene K, Danielsen MM, J, Egervarn M and Vandamme $P$ (2008). Phenotypic and molecular assessment of antimicrobial resistance in Lactobacillus paracasei strains of food origin. J Food Prot 71, 339-344.

14. Huys G, D’Haene K and Swings J (2002). Influence of the culture medium on antibiotic susceptibility testing of food -associated lactic acid bacteria with the agar overlay disc diffusion method. Lett Appl Microbiol 34, 402- 406.

15. Kievit TR and Iglewski BH (2000). Bacterial Quorum Sensing in pathogenic relationships, Infection and Immunity, 68 (8): 4839-4849.

16. Klare I, Konstabel C, Werner G, Huys G, Vankerckhoven V, Kahlmeter G, Hildebrandt B, Muller-Bertling S, Witte W and Goossens $H$ (2007). Antimicrobial susceptibilities of Lactobacillus, Pediococcus and Lactococcus human isolates and cultures intended for probiotic or nutritional use. J Antimicrob Chemother 59, 900-912.

17. Korhonen JM, Danielsen M, Mayo B, Egervarn M, Axelsson L, Huys G and von Wright A (2008). Antimicrobial susceptibility and proposed microbiological cut-off values of lactobacilli by phenotypic determination. Int J Prob Preb 3, 257-268.
18. Leclercq R, Dutka-Malen S, Brisson-Noel A, Molinas C, Derlot E, Arthur M, Duval J and Courvalin P (1992). Resistance of enterococci to aminoglycosides and glycopeptides. Clin Infect Dis 15, 495-501.

19. Lin CF, Fung ZF, Wu CL and Chung TC (1996). Molecular characterization of a plasmid -borne (pTC82) chloramphenicol resistance determinant (cat-TC) from Lactobacillus reuteri G4. Plasmid 36, 116-124.

20. Mathur S and Singh R (2005). Antibiotic resistance in food lactic acid bacteria - a review. International Journal of Food Microbiology 105:281-295.

21. Moura A, Nicolau A, Hooton T and Azeredo J (2009). Antibiotherapy and pathogenesis of uncomplicated UTI: difficult relationships, Journal of Applied Microbiology, 106, 1779-1791.

22. Roberts MC (2005). Update on acquired tetracycline resistance genes. FEMS Microbiol Lett 245, 195-203.

23. Sherman PM, Ossa JC, Johnson-Henry K (2009). Unraveling Mechanisms of Action of Probiotics. Nutrition in Clinical Practice 24: 10-14.

24. Tynkkynen S, Singh KV and Varmanen $P$ (1998). Vancomycin resistance factor of Lactobacillus rhamnosus GG in relation to enterococcal vancomycin resistance (van) genes. Int J Food Microbiol 41, 195-204.

25. Zhou JS, Pillidge CJ, Gopal PK and Gill HS (2005). Antibiotic susceptibility profiles of new probiotic Lactobacillus and Bifidobacterium strains. Int J Food Microbiol 98, 211-2. 